\title{
Retrospective Analysis of Patients With Immune Thrombocytopenic Purpura
}

\section{İmmün Trombositopenik Purpura Hastalarının Retrospektif Analizi}

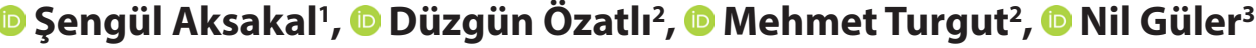 \\ 'Department of Immunology and Allergy, Training and Research Hospital, Samsun, Turkey \\ ${ }^{2}$ Department of Hematology, Ondokuz Mayıs University Faculty of Medicine, Samsun, Turkey \\ ${ }^{3}$ Department of Hematology, Pamukkale University Faculty of Medicine, Denizli, Turkey
}

\begin{abstract}
Aim: We evaluated the clinical feature and the responses to treatments in patients diagnosed and/or followed as chronic immune thrombocytopenic purpura.

Method: Medical charts of 150 patients diagnosed and/or followed as immune thrombocytopenic purpura at Ondokuz Mayıs Medical Faculty between 2003 and 2011 were analyzed retrospectively. As first-line treatments, steroids-based treatment and intravenous immunoglobulin were used as medical therapy. In patients, who had no response to first and second courses treatments, splenectomy, danazole, rituximab and other immunosuppresive drug were performed.

Results: The median follow-up of 150 patients was 15 months (range 2-83 months). Thrombocytopenia was incidentally detected in $51(34 \%)$ of the cases. During the study period, $21(14 \%)$ the patients were followed up without treatment. First line medical therapy were given to $129(86 \%)$ patients. Of them, complete response were seen in $93(72 \%)$ patients, partial response in 14 (11\%) patients and none response in $22(17 \%)$ patients. There was no significant benefit of high dose steroid therapy over the standard dose therapy $(p=0.59)$. Of the 107 patients who had response to the treatment, relapse were observed in 48 (45\%) within 2,5 years. Of 40 patients, there were complete response in 15 (38\%) patients, partial response in 9 (22\%) patients and none response in 16 (40\%) patients. Splenectomy was performed in 38 patients. Of the 48 patients, complete response was achieved in 32 (84\%) patients, partial response in $2(\% 5)$ patients and none response in $4(16 \%)$ patients. Relapse was observed in $12(35 \%)$ patients.

Conclusion: This study showed that steroids-based treatment and splenectomy are very effective treatment in immune thrombocytopenic purpura patients. Only 13 (8.6\%) patients in our study needed further treatment.
\end{abstract}

Keywords: Immune thrombocytopenic purpura, bleeding, corticosteroid, splenectomy
Öz

Amaç: Kronik immün trombositopenik purpura tanısı konan ve/veya izlenen hastaların klinik özellikleri ve tedavi yanıtları değerlendirdik.

Yöntem: Ondokuz Mayıs Tıp Fakültesi'nde 2003-2011 yılları arasında immün trombositopenik purpura tanısı konan ve/veya takibi yapılan 150 hastanın tıbbi kayıtları geriyedönük incelendi. Birinci basamak tedavi olarak steroid bazlı tedavi ve intravenöz immünglobulin kullanıldı. Birinci ve ikinci basamak tedavilerine cevap vermeyen hastalara splenektomi danazol, rituksimab ve diğer immünsüpresif ilaçlar uygulandı.

Bulgular: 150 hastanın ortanca takip süresi 15 ay (aralık 2-83 ay) idi. Olguların 51'inde (\%34) trombositopeni tesadüfen saptanmıştı. Çalışma süresi boyunca 21 (\%14) hasta tedavisiz takip edildi. 129 hastaya (\%86) birinci basamak tıbbi tedavi verildi. Bunlardan 93'ünde (\%72) tam yanıt, 14'ünde (\%11) kısmi yanıt ve 22 (\%17) hastada herhangi bir yanıt görülmedi. Yüksek doz steroid tedavisinin standart doz tedavisine göre anlamlı bir faydası yoktu $(p=0,59)$. Tedaviye yanıt veren 107 hastanın 2,5'inde 48 (\%45) nüks görüldü. 40 hastanın 15 'inde (\%38) tam yanıt, 9'unda (\%22) kısmi yanıt ve 16'sında (\%40) yanıt görülmedi. 38 hastaya splenektomi uygulandı. 48 hastadan 32 'sinde (\%84) tam yanıt, 2'sinde (\%5) kısmi yanıt ve 4'ünde (\%16) yanıt görülmedi elde edildi. On iki hastada (\%35) nüks görüldü.

Sonuç: Bu çalışma immün trombositopenik purpura hastalarında steroid bazlı tedavi ve splenektominin çok etkili bir tedavi olduğunu göstermiştir. Çalışmamızda sadece $13(\% 8,6)$ hasta daha ileri tedaviye ihtiyaç duydu.

Anahtar Kelimeler: İmmün trombositopenik purpura, kanama, kortikosteroid, splenektomi 


\section{INTRODUCTION}

Immune thrombocytopenic purpura (ITP) is an acquired and autoimmune disease characterized by low platelet count and generally mucocutaneous bleedings, which is diagnosed with the exclusion of the other causes of thrombocytopenia. ITP is classified as acute and chronic according to duration of thrombocytopenia. Acute form usually seen in children, which most often resolves spontaneously or after a short course of steroids. Chronic ITP, which occurs frequently in adults, is defined as a low platelet count which persists more than 3 months. In adults, the annual incidence of ITP is 5/100,000. It is commonly seen between 30-40 ages. In the physiopathology of the disease, the recognition of the antibody-coated platelets binding the macrophages of reticuloendothelial system through Fc receptors, primarily in the spleen, and their removal by phagocytosis plays a role. ${ }^{[1-3]}$ Steroids, intravenous immunoglobulin (IVIg) and anti-D therapies are generally considered as first-line therapy in patients with ITP. The patients who fail to respond to those therapies undergo splenectomy. For the patients who don't respond or are not eligible for those therapies, although rituximab and thrombopoietin receptor agonists (TPO-RAs) have been usually preferred nowadays, immunosuppressive therapy and/or danazole are the other treatment alternatives. ${ }^{[3,4]}$

In this study, we retrospectively evaluated the initial clinical features, the therapeutic response and the clinical course in 150 patients with chronic ITP at our center.

\section{MATERIAL AND METHOD}

In this study, we retrospectively reviewed the medical charts of 150 patients diagnosed and/or followed as ITP at Ondokuz Mayıs Medical Faculty, Department of Internal Diseases, Division of Hematology between 2003 and 2011. All patients had chronic ITP, which was defined as a platelet count $<150,000 / \mathrm{mm}^{3}$ that had been present for at least 3 months with no clinical or laboratory findings that could account for it. In addition to a detailed physical examination and drug history, the whole blood count, evaluation of the stained peripheral blood smear, biochemical profile, routine tests of hemostasis, serological tests for HIV and hepatitis B (HBV) and $C$ (HCV) viruses, and antinuclear antibody (ANA) and antidouble-stranded DNA (anti-ds-DNA) for collagen vascular diseases were studied.

Treatment was given to patients with a platelet count below $30,000 / \mathrm{mm}^{3}$ and/or bleeding. As first-line treatments, steroids based treatment including standard dose steroids (SDS) (1 $\mathrm{mg} / \mathrm{kg} /$ day), high dose steroids (HDS) ( $30 \mathrm{mg} / \mathrm{kg} /$ day steroids for 3 days) or high dose dexametazon (HDD) ( $40 \mathrm{mg}$ for 4 days), intravenous immunoglobulin (IVlg)( $1 \mathrm{gr} / \mathrm{kg}$ for 2 days) or combination treatments (HDS followed by SDS or IVlg + SDS) were used as medical therapy. A second course of steroids treatment was given to relapsed patients. When platelet count $>150,000 / \mathrm{mm}^{3}$ was reached, steroids was gradually tapered off within several weeks. For patients who were refractory to first-line treatment or for relapsed patients who had no response to a second course steroids treatment, splenectomy was as second- or third-line therapy. Immunosuppressive therapy (azathioprine and cyclosporine) and/or danazole were given to patients refractory to splenectomy and steroids based treatment. During the study period, TPO-RAs were not available in our country and rituximab was used for the treatment of 2 patients in the last 2 years of the study. Posttreatment response was considered as complete response (CR) with a platelet count $150,000 / \mathrm{mm}^{3}$ lasting $\geq 4$ weeks, partial response (PR) with a platelet count of 50,000-150,000/ $\mathrm{mm}^{3}$ lasting $\geq 4$ weeks and no response (NR) with a platelet count $<50,000 / \mathrm{mm}^{3}$.

Data obtained in the study were evaluated by using SPSS 15.0 software for statistical analysis. Mann-Whitney $\mathrm{U}$ and $\mathrm{Chi}$ square tests were used for the statistical difference and the statistical significance level was considered as $p<0.05$.

This manuscript derived form Dr Şengül Aksakal's doctorate thesis 2011/281701 Ondokuz Mayıs University School of Medicine Internal Medicine

\section{RESULTS}

Twenty-five of 150 patients had diagnosed with ITP in another health center, but their treatments and clinical follow-ups were done in our center. Of 150 patients with ITP, 108 (72\%) were female and $42(28 \%)$ male. The mean age was $44 \pm 18$ years (range 18-91). At the time of admission, 92 (61.3\%) patients had cutaneous bleeding, $22(14.7 \%)$ patients gingival bleeding, 10 (6.7\%) patients had epistaxis and 6 (4\%) patients had vaginal bleeding. In the follow-ups, hematuria was seen in $2(1.3 \%)$ patients, upper gastrointestinal tract bleeding in $2(1.3 \%)$ patients, and intracranial hemorrhage in $2(1.3 \%)$ patients. Fifty-one (34\%) patients had no sign and symptom of bleeding. Two (1.3\%) patients had leucopenia $(<4 \times 109 / /)$. Fifty-six (49 female and 7 male) (37.3\%) patients had anemia. All anemic patients had iron deficiency anemia. ANA and anti-ds-DNA was determined in 84 (56\%) patients. ANA was positive in 16 patients. No patient had positive for anti-dsDNA. HBV surface antigen was positive in 2 patients who were carrier. Anti-HCV was positive in 2 patients, but PCR HCV RNA was negative in both.

The median follow-up of all 150 ITP patients was 15 months (2 months-83 months). In 36 (24\%) patients, there was no therapeutic indication at the diagnosis. During followedup, only 21 patients did not receive any treatment because they had a platelet count above $30,000 / \mathrm{mm}^{3}$, and no signs and symptoms of bleeding. One hundred-twenty-nine were received medical treatment (Table 1). CR were seen in 93 (72\%) patients, PR in $14(11 \%)$ patients and NR 22 (17\%) patients. High dose steroids therapy had no significant benefit over the standard dose therapy ( $p=0.59)$. There was no statistically difference between male and female individuals in terms of response to first-line therapy $(p=0.42)$. 
Table 1. The first-line treatment modalities and response to therapy in ITP patients

\begin{tabular}{lcccc} 
Therapy & $\begin{array}{c}\text { Number of } \\
\text { patient }\end{array}$ & $\begin{array}{c}\text { Complete } \\
\text { response }\end{array}$ & $\begin{array}{c}\text { Partial } \\
\text { response }\end{array}$ & $\begin{array}{c}\text { No } \\
\text { response }\end{array}$ \\
\hline SDS & $68(52.7 \%)$ & $49(72 \%)$ & $6(8.8 \%)$ & $13(19.2 \%)$ \\
HDS & $17(13.2 \%)$ & $13(76 \%)$ & $1(5.8 \%)$ & $3(18.2 \%)$ \\
IVlg & $7(5.4 \%)$ & $5(71 \%)$ & $2(29 \%)$ & - \\
HDT & $4(3.1 \%)$ & $4(100 \%)$ & $0(0.0 \%)$ & - \\
HDS+SDS & $21(16.3 \%)$ & $14(66.6 \%)$ & $3(14.2 \%)$ & $4(19.2 \%)$ \\
IVlg+SDS & $12(9.3 \%)$ & $8(66.6 \%)$ & $2(16.6 \%)$ & $2(16.6 \%)$ \\
Total & $129(100 \%)$ & $93(72.1 \%)$ & $14(10.8 \%)$ & $22(17.1 \%)$ \\
\hline
\end{tabular}

SDS: standard dose steroids, HDS: high dose steroids, IVIg: intravenous immunoglobulin, HDD; high dose dexametazon

Of the 107 patients who had response to the first line treatment, relapse were observed in 48 (45\%) patients in 2.5 years. Twenty-seven (56\%) patients had relapse in one year. Of them eight patients had platelet counts $>30,000 / \mathrm{mm}^{3}$ and no signs and symptoms of bleeding, and was followed up without treatment. A second course of medical treatment was given to 40 relapsed patients. Of them, CR was seen in 15 (38\%) patients, PR in 9 (22\%) patients and NR in 16 (40\%) patients (Table $\mathbf{2}$ ).

Table 2. The second course medical treatments and response to therapy in ITP patients relapsing after the first-line treatments

\begin{tabular}{lcccc} 
Therapy & $\begin{array}{c}\text { Number of } \\
\text { patient }\end{array}$ & $\begin{array}{c}\text { Complete } \\
\text { response }\end{array}$ & $\begin{array}{c}\text { Partial } \\
\text { response }\end{array}$ & $\begin{array}{c}\text { No } \\
\text { response }\end{array}$ \\
\hline SDS & $26(65 \%)$ & $10(38.5 \%)$ & $5(19.2 \%)$ & $11(42.3 \%)$ \\
HDS & $4(10 \%)$ & - & $2(50 \%)$ & $2(50 \%)$ \\
IVlg & $1(2.5 \%)$ & - & $1(100 \%)$ & - \\
HDD & $3(7.5 \%)$ & $1(33.4 \%)$ & - & $2(66.6 \%)$ \\
HDD+SDS & $3(7.5 \%)$ & $2(66.6 \%)$ & $1(33.4 \%)$ & - \\
IVlg+SDS & $3(7.5 \%)$ & $2(66.6 \%)$ & - & $1(33.4 \%)$ \\
Total & $40(100 \%)$ & $15(38 \%)$ & $9(22 \%)$ & $16(40 \%)$ \\
\hline
\end{tabular}

SDS: standard dose steroids, HDS: high dose steroids, IVIg: intravenous immunoglobulin, HDD; high dose dexametazon

Splenectomy was undertaken in 38 patients. In 22 patients splenectomy was performed as the second-line therapy and in 16 as third-line therapy. CR was achieved in 32 (84.1\%) patients, PR in 2 (\%5.3) patients and NR in 4 (\%10.6) patients. Relapse was observed in 12 (35.3\%) patients of 34 patients responding to splenectomy. Of 12 patients, 2 patients had achieved CR after steroids treatment and 1 patient was followed up without treatment because this patient had platelet count $>30,000 / \mathrm{mm}^{3}$, and no signs and symptoms of bleeding.

Despite therapies including splenectomy, steroids and IVIg, severe thrombocytopenia persisted in 13 patients. Eleven of 13 patients received azathioprine and remaining 2 patients take cyclosporine. Response to azathioprine treatment was seen in 6 patients. Three of those 6 patients had platelet count $>100,000 / \mathrm{mm}^{3}$, platelet count $>50,000 / \mathrm{mm}^{3}$ in 1 patient and platelet counts $>30,000 / \mathrm{mm}^{3}$ in 2 patients. Two of 5 patients, who had no response to azathioprine, achieved PR after cyclosporine plus danazole treatment and other one patient had platelet count $>30,000 / \mathrm{mm}^{3}$ after rituximab treatment. The other 2 patients died from intracranial bleeding.

\section{DISCUSSION}

Immune thrombocytopenia is an autoimmune hematological disorder characterized by persistently low circulating platelets due peripheral causes. Although the etiopathogenesis of ITP is not known clearly, it is mostly recognized that the low platelet count observed in ITP patients is due to disregulation between platelet production and destruction. As the disease affects platelets, the main complaints of patients are bleeding and complications related to bleeding. Therefore, it is very important for patients to be diagnosed quickly and to start treatment early.

At the time of diagnosis, most of ITP patient has bleeding. [5-7] Platelet counts of patients newly diagnosed with ITP are an important indicator of bleeding risk, while many of them require only observation, patients with very low platelet counts have high bleeding risks. The most common bleeding types are purpura, epistaxis and gingival bleeding. Hematuria, gastrointestinal and intracranial bleeding are less common. There was no therapeutic indication in 36 (24\%) patients at the diagnosis in our study. During the follow-up 15 months (2-83 months), 21 (14\%) patients did not receive any therapy. In their study, Cortelazzo et al. ${ }^{[8]}$ documented that the percentage of the patients who did not receive the therapy was $41.8 \%$. In our study, a total of 98 (66\%) patients had findings of bleeding. During the follow-up, it was developed hematuria in 2 patients, gastrointestinal bleeding in 2 patients and intracranial hemorrhage in 2 patients.

There are three main goals of the ITP treatment: to rapid increase of platelet count for reduce bleeding risk, to maintain a stable, hemostatic platelet count, or remission of the disease. $[9,10]$ A stepwise approach is recommended in the disease according to the treatment response. The first line treatment option is corticosteroids. Approximately $80 \%$ of patients are expected to respond to steroid treatment, but recurrence rates are high during the reduction and discontinuation of steroids. Differences in steroid therapy application can affect the response of patients. ${ }^{[1]}$ A prospective study showed that while initial response rates between prednisone and dexamethasone were both 100\%, long-term remission was significantly more frequent with pulsed dexamethasone at $77 \%$ vs. $22 \%$ with daily prednisone. ${ }^{[12]}$ In our study, 110 patients received steroids based treatments and the respond to the treatments was seen in 90 (81.7\%) (CR 72.7\% and PR 
9\%), which was consistent with literature. ${ }^{[13-15]}$ Although there were conflict data in the literature, high dose steroids therapy had no significant benefit over the standard dose therapy in our study $(p=0.59) .^{[15-18]}$ There are some studies that showed the rate of complete response with steroid therapy was higher in women. ${ }^{[19,20]}$ In our study, similar success rate was found in term of gender $(p=0.42)$. As the first-line treatment 7 patients received only IVlg and 12 patients IVlg+SDS. CR rates were around $70 \%$. After the first-line treatment, relapse were observed in $48(45 \%)$ patients within 2.5 years. Twentyseven (56\%) patients had relapse in one year. A second course of medical treatments were given to 40 relapsed patients. Although the response rates were not good as in the first-line treatment, CR was seen in 15 (38\%) patients, PR in 9 (22\%) patients (Table 2). Thus, we conclude that steroids are an effective treatment modality both as first-line and second-line therapies.

In addition to the production of antiplatelet antibodies, the spleen plays an important role in this disease as it indicates platelet destructions. Splenectomy in adults can be perform in patients who fail to respond to steroids, develop thrombocytopenia after taper, or develop steroid toxicity. ${ }^{[2]]}$ Depre et al. ${ }^{[22]}$ found that $60 \%$ of ITP patients had sustained remission after splenectomy. Although the results of splenectomy are satisfactory, relapses are reported. It was shown in the study of Guan colleagues ${ }^{[23]}$ that while $\% 88$ of 174 patients have good success after splenectomy, $\% 20$ of them relapsed. In our study splenectomy was performed in 38 patients. CR was achieved in 32 (84.1\%) patients, PR in 2 (\%5.3) patients, which was consistent with literature. ${ }^{[24,25]}$ Relapse was observed in 12 (35.3\%) patients. During follow-up 22 (57.9\%) patients were still in remission. Despite splenectomy, steroids and IVIg therapies, severe thrombocytopenia persisted in $13(\% 8.6)$ patients in our study. Nine of 13 patients still had response to azathioprine, cyclosporine and danazole or combination of them. During the study period, TPO-RAs was not available in our country and rituximab was used for only 2 patients resistant to all the treatments and the platelets levels of those patients raised $>30,000 / \mathrm{mm}^{3}$.

As a result, this study showed that steroids-based treatment and splenectomy are very effective in treatment of ITP patients.

\section{ETHICAL CONSIDERATIONS}

Ethics Comittee Approval: According to the Regulation on Clinical Researches published in the official newspaper with the number 28617 dated 3 November 2015, the ethics committee approval was not obtained in accordance with the article "Retrospective studies are outside the scope of the regulation (article 2- (2))". This study was prepared in accordance with the Law on Protection of Personal Data, by anonymizing patient data and in accordance with the 2013 Brazil revision of the Helsinki Declaration and guidelines for Good Clinical Practice.
Informed Consent: Because the study was designed retrospectively, no written informed consent form was obtained from patients.

Status of Peer-review: Externally peer-reviewed.

Conflict of Interest Statement: The authors have no conflicts of interest to declare.

Financial Disclosure: The authors declared that this study has received no financial support.

Author Contributions: All of the authors declare that they have all participated in the design, execution, and analysis of the paper, and that they have approved the final version.

Acknowledgements: This manuscript derived form Dr Şengül Aksakal's doctorate thesis 2011/ 281701 Ondokuz Mayıs University School of Medicine Internal Medicine

\section{REFERENCE}

1. Segal JB, Powe NR. Prevalence of immune thrombocytopenia: analyses of administrative data. J Thromb Haemost 2006;4(11):2377-83.

2. Guthrie TH, Jr., Brannan DP, Prisant LM. Idiopathic thrombocytopenic purpura in the older adult patient. Am J Med Sci 1988;296(1):17-21.

3. Cines DB, Bussel JB. How I treat idiopathic thrombocytopenic purpura (ITP). Blood. 2005;106(7):2244-51.

4. Matzdorff A, Arnold G. Treatment of chronic immune thrombocytopenic purpura: the patients' perspective. Eur J Haematol 2007;78(5):381-8.

5. Portielje JE, Westendorp RG, Kluin-Nelemans HC, Brand A. Morbidity and mortality in adults with idiopathic thrombocytopenic purpura. Blood. 2001;97(9):2549-54.

6. Vianelli $N$, Valdre $L$, Fiacchini $M$, et al. Long-term follow-up of idiopathic thrombocytopenic purpura in 310 patients. Haematologica. 2001;86(5):504-9.

7. Pamuk GE, Pamuk ON, Baslar Z, et al. Overview of 321 patients with idiopathic thrombocytopenic purpura. retrospective analysis of the clinical features and response to therapy. Ann Hematol 2002;81(8):43640

8. Cortelazzo S, Finazzi G, Buelli M, Molteni A, Viero P, Barbui T. High risk of severe bleeding in aged patients with chronic idiopathic thrombocytopenic purpura. Blood. 1991;77(1):31-3.

9. Mithoowani S, Arnold DM. First-Line therapy for Immune thrombocytopenia. Hamostaseologie. 2019;39(3):259-65.

10. Marini I, Bakchoul T. Pathophysiology of autoimmune thrombocytopenia current insight with a focus on thrombopoiesis. Hamostaseologie. 2019;39(3):227-37

11.Samson M, Fraser W, Lebowitz D. Treatments for trimary immune thrombocytopenia: a review. Cureus 2019;11(10):e5849.

12. Matschke J, Müller-Beissenhirtz H, Novotny J, et al. A randomized trial of daily prednisone versus pulsed dexamethasone in treatment-naïve adult patients with immune thrombocytopenia: EIS 2002 study. Acta Haematol 2016;136(2):101-7

13. George JN, Woolf SH, Raskob GE, et al. Idiopathic thrombocytopenic purpura: a practice guideline developed by explicit methods for the American Society of Hematology. Blood. 1996;88(1):3-40.

14. Dameshek W, Rubio F Jr., Mahoney JP, Reeves WH, Burgin LA. Treatment of idiopathic thrombocytopenic purpura (ITP) with prednisone. Journal of the American Medical Association. 1958;166(15):1805-15.

15. Mazzucconi MG, Francesconi M, Fidani P, Di Nucci G, Gandolfo GM, Afeltra A, et al. Treatment of idiopathic thrombocytopenic purpura (ITP): results of a multicentric protocol. Haematologica. 1985;70(4):329-36. 
16. Altintop L, Albayrak D. Oral high-dose methylprednisolone and intravenous immunoglobulin treatments in adult chronic idiopathic thrombocytopenic purpura. Am J Hematol 1997;56(3):191-2.

17. Godeau B, Zini JM, Schaeffer A, Bierling P. High-dose methylprednisolone is an alternative treatment for adults with autoimmune thrombocytopenic purpura refractory to intravenous immunoglobulins and oral corticosteroids. Am J Hematol 1995;48(4):282-4.

18. Alpdogan O, Budak-Alpdogan T, Ratip S, et al. Efficacy of high-dose methylprednisolone as a first-line therapy in adult patients with idiopathic thrombocytopenic purpura. Br J Haematol 1998;103(4):1061-3.

19. den Ottolander GJ, Gratama JW, de Koning J, Brand A. Long-term followup study of 168 patients with immune thrombocytopenia. Implications for therapy. Scand J Haematol 1984;32(1):101-10.

20. Shashaty GG, Rath CE. Idiopathic thrombocytopenic purpura in the elderly. Am J Med Sci 1978;276(3):263-7.

21.George JN, Woolf SH, Raskob GE, et al. Idiopathic thrombocytopenic purpura: a practice guideline developed by explicit methods for the American Society of Hematology. Blood 1996;88(1):3-40.

22. Depre F, Aboud N, Mayer B, Salama A. Efficacy and tolerability of old and new drugs used in the treatment of immune thrombocytopenia: results from a long-term observation in clinical practice. PLoS One. 2018;13(6):e0198184.

23. Guan $Y$, Wang $S$, Xue $F$, et al. Long-term results of splenectomy in adult chronic immune thrombocytopenia. Eur J Haematol 2017;98(3):235-41.

24. British Committee for Standards in Haematology General Haematology Task Force. Guidelines for the investigation and management of idiopathic thrombocytopenic purpura in adults, children and in pregnancy. $\mathrm{Br} J$ Haematol 2003;120(4):574-96.

25. Quiquandon I, Fenaux P, Caulier MT, Pagniez D, Huart JJ, Bauters F. Reevaluation of the role of azathioprine in the treatment of adult chronic idiopathic thrombocytopenic purpura: a report on 53 cases. Br J Haematol 1990;74(2):223-8. 